\title{
GIRL'S EDUCATION IN TURKEY: AN ANALYSIS OF EDUCATION POLICIES FROM A FEMINIST PERSPECTIVE
}

\author{
Berna Çöker ${ }^{\mathrm{i}}$ \\ Dokuz Eylül University, \\ Faculty of Education, \\ Turkey
}

\begin{abstract}
:
In this study, I aim to provide an analysis of gender equality in the Turkish education system by looking at policies and their outcomes on girl's schooling. My goal is to demonstrate the ways educational policies have been complicit in reproducing inequality and difference between the sexes by examining what issues regarding education and gender have become a part of public discourse, and which issues have not. The investigation of the role of the state in contributing to gendered outcomes in education is operationalized by two data gathering processes. The first is document analysis of policy documents directly related to education which are Article 42. of the Constitution, Basic Law of National Education. Law 1739, and Basic Education Reform Act. No. 4306. The second is the collection of educational statistics and documents that would shed light to the condition of girls' education in Turkey. The central finding of the study is that the educational policies and practices in Turkey are based on the premises of "formal equality" and "meritocracy" which aims to provide the same opportunities to every member of society. However, the functional view of schooling based on the concepts of "formal equality" and "meritocracy" fosters the belief that males and females are benefitting equally and serve to mask the inequitable distribution of knowledge and skills between men and women. Therefore, educational policies continue to be gender-neutral, far from challenging the gender dynamics that discriminate against girls and women. Article 42. of the Constitution, the Basic Law of National Education. Law 1739., the Basic Education Reform Act. No. 4306 and its extension, 4+Reform, focuses on the expansion and improvement of primary and secondary education, but does not carry any special measures to change the structures and relations that discriminate against girls. No national policies to counter the impact of negative socialization by curriculum and textbook revision have been adopted. Moreover, high female attrition rates especially in the underdeveloped regions of Turkey continue to exist. Gender-streaming is still apparent in the program choices made in vocational and higher education. Turkey
\end{abstract}

i Correspondence: email bernacoker@gmail.com, berna.coker@deu.edu.tr 
depends on macro education policies without any gender differentiation to ensure educational equality.

Keywords: gender equality, critical feminist approach, educational policies, formal equality, equal opportunity policies, meritocracy

\section{Introduction}

In most countries, especially with the international pressure on gender equality, governments are taking various measures to alleviate the existing disparities between men and women. These efforts can be seen in various forms, from specific gender policies to national action plans. The Dakar conference on "Engendering Equality: Education and Empowerment" by the UN Girls' Education Initiative (UNGEI) held in 2010 highlighted the need to ensure that gender equality needs to be at the center of all educational practices. The level to which countries may respond to gender concerns very much depend on the level of pressure women grassroots insert, the leverage women's machinery has over the state and the current political agenda of the government (Sutherland, 1999). The State, with its role in policy formation plays an important role in the elimination of gender disparities at all levels of education and achievement of gender equality (Ali et al, 2004).

Theories of the state and gender from the feminist perspective have focused on gender relations and gender inequality reflected in the state as well as created by the state (Randall \& Waylen, 1988). The state is seen as key player in the construction and legitimization of gender divisions and gender identities. Countless studies of state policies- whether expressed through welfare programs, laws, educational institutions, interventions in the labor market, family policies-conclude that state actions affect the ways in "which feminine and masculine lives are constructed" (Jenson, 1986, p.9). Yet, while such observations suggest that the state activity does contribute to the constitution of gender inequality, observation of such effects do not constitute any explanation why it exists. Thus, such an explanation is best sought by an examination of the theories of state from a feminist perspective. The following section will examine the theories of the state and gender from three feminist perspectives- liberal, social and radical- and how they define social equality and give shape to gender policies in education.

\section{Theoretical Background}

\subsection{State, Gender and Equality}

While liberal feminists see the state as a structure that is serving the interests of men, but, can be turned around to serve those of women, radical feminists see it as an oppressor, a patriarchal structure of power that needs to go. Liberal feminists advocate the liberal view of the state as neutral arbiter between conflicting interests (Kenway, 1990). The state is not inherently patriarchal but rather an entity that is representing the interests of the dominant group. The reason why states happen to serve male interests is because almost 
all high level and administrative positions are occupied by men. (Peterson \& Runyan, 1993). When there is a lack of female participation and representation at the state level, women's interests are not served. The reason for the lack of specific gender policies and programs, and insufficient implementation and ineffectiveness of those that happen to exist is contributed to the lack of women representatives in decision-making positions and not enough grassroots pressure from below. Liberal feminists have a strong belief in the power of the state to protect women once women are able to achieve representation within its power structure and to exert sufficient pressure.

The liberal feminist perspective holds that equality of access and opportunities are attainable goals if the shortcomings of the system are eliminated. State legislation can help to accomplish equal opportunities for the sexes. Through state, legislation can help to secure equal opportunities for women, alter sex stereotyping and socialization processes and eradicate sex discrimination. The liberal thought has given importance to the "starting-gate" equality as well as removing the barriers to equality that prevent women from taking advantage of those opportunities. Thus, non-discrimination laws as well as gender specific laws are a high priority on the agenda of liberal feminists. The motto advocated by liberal feminists "equal and the same" took the "male" as the standard for comparison, and social equalization meant "catching up" to men (David, 2004). The liberal stance was criticized in terms of individualizing women's problems by focusing solely on obtaining equal rights and equal opportunities through litigation (Baron, 1987).

The socialist and radical views of the state are very much skeptical about the role and capacity of the state to achieve gender equality (Eisenstein, 1979, McIntosh, 1978, MacKinnon, 1983; Burstyn, 1985; Walby, 1990, Maslak, 2005). It is argued that with nondiscrimination laws women are granted equal protection of the laws only to the extent that they are "similarly situated" to men (Eisenstein, 1988; Baron, 1987). Legislations needed to move beyond the view of equality as the "sameness of treatment" to equality as "different treatment" (Schaar, 1971: Baron, 1987) Simple versions of equal opportunity Schaar (1971, p. 142) argues would "presume, reproduce and magnify inequality in a society by having unlike individuals submit to a single pattern of achievement in an unequal competition ...much of the demand for equality is really a demand for an equal right and opportunity to become unequal". Therefore, liberal feminists were criticized in their efforts to obtaining legal rights, emphasizing formal equality as an end in itself, rather than seeking structural changes to achieve substantial equality (Petchesky, 1984).

Liberal feminist conceptualizations of gender equality which is based on the notion of distributive justice neglects to focus on the social structure and institutional contexts that help to systematically disadvantage women (Hauserman, 1983). Hence, equality of opportunity is not enough to achieve equality of outcome, which needs to be the main priority if women's subordination is to be eradicated. Thus, legislation required to enact equal opportunity policies are questioned in terms of whether they can remedy social injustice or simply reinforce inequality by making it appear less discriminatory. Petchesky (1984, p.7) argues that equal opportunity laws are about giving rights that are "demands for access for oneself, or for 'no admittance' to others, but they do not challenge the social structure, the social relations of production and reproduction". 


\subsection{Turkish Education Policies and Equality: An analysis for Women}

The Global Gender Gap Report published annually by the World Economic Forum assesses 134 countries in terms of rights and freedoms of women and shows the magnitude of gender-based disparities across four dimensions (economic, education, health and political). In the 2020 Ranking, Turkey ranked 130th among 153 countries as for the equality of women and men. Concerning women's equal access to education, Turkey occupies 113th place (World Economic Forum, 2020). These results indicate that for Turkey there is still a long way to go to achieve gender equality. Many studies on gender and education in Turkey have dealt with the existing gender disparities in enrollment, attainment and completion rates of girls and boys in formal education (Demiray, 2015; Gümüş \& Chudgar, 2016; O’Dwyer, Aksit, and Sands, 2010). However, the policy understanding of equality, which rests on gender parity focusing on distributive justice neglects to focus on the structural problems girls face (Murphy \& Elwood, 1998; Francis \& Skelton, 2005; Unterhalter, 2005). In this study, I aim to provide an analysis of gender equality in the Turkish education system by looking at policies and their outcomes on girl's schooling. My goal is to demonstrate the ways educational policies have been complicit in reproducing inequality and difference between the sexes by examining what issues regarding education and gender have become a part of public discourse, and which issues have not. The interpretation of policies and practices are primarily framed through a critical feminist framework using gender as an analytic category in addressing inequities.

\section{Methods}

Although it would be impossible to form a linear link between educational policies and practices with educational outcomes, policies are tools that can both exacerbate or reduce the existing inequalities. However, if policies are the operational statements of values, "statements of prescriptive intent" (Kogan 2018, p.55), we need to ask whose values are validated in policy, and whose are not. The authoritative allocation of values draws our attention to the "centrality of power and control in the concept of policy" (Prunty 1985, p.136). Then, policies cannot be divorced from interests, from conflict, from domination or from justice. Discontinuities, compromises, omissions, and exceptions are also important. Therefore, it would not be wrong to attribute to a certain extent, the gendered patterns in educational outcome to the nature of the policies implemented at the educational level.

The investigation of the role of the state in contributing to gendered outcomes in education is operationalized by two data gathering processes. The first is document analysis of policy documents and the second is the collection of educational statistics and documents that would shed light to the condition of girls' education in Turkey. The data draws on policies directly related to education to understand how gender equality is conceptualized. The policy documents that are analyzed are the legislation documents concerning the provision of education in Turkey. These are Article 42 of the Constitution, Basic Law of National Education Law 1739 and Basic Education Reform Act No:4306. Published statistics on the enrollment in primary and secondary education and 
enrollment in different types of institutions and programs were utilized to examine women's conditions and substantiate the findings of policy analysis that was conducted. The analysis of documents was conducted from a feminist critical analysis approach. Marshal identifies feminist critical analyses as, "research that conducts analyses for women while focusing on policy and politics" (1997, p.2). This perspective she states, "begins with the assumption that gender inequity results from purposeful (if subconscious) choices to serve some in-group's ideology and purpose. It is research identifying how the political agenda benefiting white males is embedded in social structures and practices." (1997, p.2). This study conveys a feminist critical perspective which is concerned in identifying which gender groups' interests seem to be served or undermined by the value systems informing the preferences, priorities and silences of the policy documents.

The following questions will set the framework for the policy analysis:

- How are problems defined? What is the intended purpose? What is the problem, if any in terms of women's conditions and how is it attempted to be solved?

- What kind of solutions has been proposed? What is the intended outcome? What does this indicate?

- How will this policy be effective in attaining gender equality?

- What kind of theoretical base does the policies rest upon?

\section{Results and Discussion}

\subsection{Article 42 of the Constitution}

Article 42 is directly related to education, and sets up the scope of Law No. 1739., the Basic Law of National Education. Article 42 assigns the control and administration of all educational activities to the State and mandates primary education to be compulsory for all citizens. A closer examination of article 42 reveals three main themes embedded in its context: equality, social integration, and centralized control. The concept of equality is emphasized through the provision of free, compulsory primary education and provision of scholarships and financial assistance. Social integration is emphasized through conducting education along the lines of Ataturk's reforms for the purpose of promoting and establishing a single, national identity. Centralized control is emphasized through state regulation of all educational provision. The statements that fall under the equality perspective in Article 42 of the Constitution are as follows:

"No one shall be deprived of the right of education.

Primary education is compulsory for all citizens of both sexes and is free of charge in state schools.

The principles governing the functioning of private primary and secondary schools shall be regulated by law in keeping with the standards set for the state schools.

The State shall provide scholarships and other means of assistance to enable students of merit lacking financial means to continue their education. The State shall take necessary measures to rehabilitate those in need of special education so as to render such people useful to society." 
Article 42 of the Constitution establishes three primary measures to be carried out by the state for the achievement of social equality. The first is the provision of free education at the primary level, the second is the provision of scholarships and assistance in accord with ability and socio-economic status, and the third is the provision of special education to the gifted and physically disabled. Gender is given consideration only in regard to primary education being compulsory for both sexes.

\subsection{Basic Law of National Education, Law 1739}

The Basic Law of National Education, which closely adheres to Article 10 and Article 42 of the Constitution establishes the basis of the Turkish National Education system, and is the principle legislation in the formation of all the other policies and laws designed and implemented in the field of education. Three principles of the Basic Law of National Education set the boundaries and the scope of the right to education. These are the principles of "Universality and Equality", the "Right to Education" and "Equality of Opportunity".

"Universality and Equality: Article 4.

Educational institutions are open to every individual regardless of language, race, sex and religion. No individual, family, group, or class will be accorded any privilege in the education system.

Right to education: Article 7.

It is the right every Turkish citizen to receive basic education. Citizens can take advantage of post-basic education institutions commensurate to their interests, aptitudes and abilities.

\section{Equality of Opportunity. Article 8.}

All citizens, male and female, are assured equal educational opportunity. Necessary assistance in the form of free boarding facilities, scholarships, loans, etc. is given to successful students who lack the financial resources, to enable them to pursue their education to the highest level.

Special measures are taken to train those children who are in need of special education and protection." (Binay, 1992, p.7-8)

The principle of "right to education" rules "basic education" to be the fundamental right of every individual and the provision of post-basic education to be commensurate with one's abilities. The meritocracy perspective is also reflected in the five-year development plans, especially in the first two five-year plans of Turkey that covers the years between 1963-1973. In the Second Five-year Development Plan (1968-1973) it states "the provision of post-basic educational opportunities to citizens will be based on the principle of equal opportunity.... The ones who will be able to take advantage of the limited educational opportunities will be selected... merit will be taken as a measure" (MONE-APK, 1993, p.29-30). Thus, while basic education is made available to all, merit plays an important role in 
determining who takes advantage of post-basic education. The theoretical base of article 7 , the right to education, rests upon on a functionalist view of schooling, closely linked to the concept of a meritocratic society. The assumption of a meritocratic society is part of an optimistic, liberal ideology that stresses the importance of ability in contemporary industrialized society and the school's role in searching out that ability (Kariya \& Rappleye, 2020). It explains unequal outcomes as a function of individual differences in motivation and intellectual ability. From this perspective, the prevalent gender differences in access and attainment in post-basic education can only be explained in terms of girls having less motivation and intellectual ability than boys. A meritocratic ideology of equal opportunities fails to deal with gender as a main social construct that leads to unequal educational outcomes.

The third principle, equality of opportunity, mandates that everyone, male and female, will be provided equal opportunity. Social class and disability are identified as the two main variables that can obstruct individuals from taking advantage of educational opportunities. Both Article 42 of the Constitution and Law 1739 provide special consideration to two groups: the disabled and the socio-economically disadvantaged. According to both laws supportive incentives such as scholarships, free boarding, etc., are to be provided to those who have the interest, aptitude, and ability to pursue higher levels of education but do not have the financial means to do so. Also, it promotes taking special measures to train children who are need of special education and protection.

Social class and disability are considered as decisive factors of advantage and disadvantage, but sex is not. Although Gender was added as separately to Article 10 of the Constitution requiring the State to act and take measures to maintain gender equality, no such constituents have been added to Basic Law of National Education, Law 1739. The Basic Law of National Education, Law 1739 reveals sensitivity towards individuals from low social economic status and individuals with disability. However, the fact that girls just because of their gender can be deprived of educational opportunities is not identified as a problem. Concerns for girls' chastity, household poverty and the need for girls' labor at home, gender role attitudes, and early marriages were found to be just some of the obstacles for female education in Turkey (Börkan et al., 2014; Gümüş \& Chadgar, 2015; Alat \& Alat, 2019).

The provision of equal opportunity also brings with itself the notion of fair competition which is important in maintaining political stability. Those who have been rewarded, as well as those who have not, believe that they competed under a fair system of rules. Tests are utilized to identify talented people from all classes in society. Thus, they provide the means for a fair system that promotes selection or screening of people based on talent. Vocational guidance in Turkey is based upon this notion of fair competition and individual merit and thus, school and programs election are designed to be made in accord with one's skills and talents.

Article 5, "Individual and Social Needs" and Article 6, "Orientation" of the Basic Law of National Education are the two principles that provide the scope of vocational guidance in Turkey. 
"Individual and Social Needs: Article 5.

The national education service is organized in accordance with the interest and abilities of the citizens of Turkey and the needs of the Turkish society.

Orientation: Article 6.

Individuals are directed into various programs or schools in accordance with their interests, aptitudes and abilities throughout their education.

The national education system is to be organized to realize this orientation fully.

Guidance services and objective testing and measurement methods are used in the orientation, and evaluating their success." (Binay, 1992, p.7)

Article 24 of the School Guidance Services Regulations also states that "the purpose of guidance councils is to assist students in becoming familiar with different occupations and social values and to help them choose education programs in accord with their skills". The provision of vocational guidance in accord with one's talents and skills has been emphasized in all of the Five-Year Development Plans as well as in the resolutions taken in the VII, VUI, IX, XII, XV, and XVI National Education Conventions. However, the rationalization of a meritocratic society undermines the sex-stereotyped beliefs and expectations that direct women into choosing traditional subject areas that lead mostly to low-paying and deadend jobs. Role specific and culture specific expectations of society have been recognized as strong determinants in the career choices of boys and girls, men and women (Pratt, Bloomfield, \& Seale, 1984; Ball \& Gerwirtz, 1997). Expectations of what is appropriate work for women and men are fairly traditional, and still have a large effect in determining the program choices made by boys and girls.

The Turkish Higher Education Statistics of 2019-2020 reveals the obvious genderstreaming apparent in program choices. Table 1 shows the percentage of males and females enrolled in institutional programs of higher education.

According to the Higher Education Statistics of 2019-2020, females constitute the majority of the student population in education, arts and humanities and nursing whereas males constitute the majority of the student population in Engineering, Business Administration, Economics and Technology. In order for policies to address gender streaming, there first needs to be a recognition on the part of policy makers that choices made in regards to courses and disciplines are not simply a question of individual preference but are the result of socialization messages that lead to those choices (Pratt et. al, 1984, Riordin, 1990). 
Table 1: Number and Percentage of Male and Female tertiary education students by program in 2019-2020

\begin{tabular}{lccccc}
\hline \multirow{2}{*}{ Program } & Total & \multirow{2}{*}{ Male } & \multirow{2}{*}{ Female } & \multicolumn{2}{c}{ \% by Sex } \\
& Enrollment & & & M & F \\
\hline Computer and Information Sciences & 3,478 & 2762 & 716 & 79.4 & 20.6 \\
\hline Marine Sciences & 6,747 & 5,807 & 940 & 86 & 14 \\
\hline Civil Engineering & 6.276 & 4,769 & 1,507 & 76 & 24 \\
\hline Mechanical Engineering & 5,606 & 4,722 & 884 & 84.2 & 15.8 \\
\hline Engineering and Natural Sciences & 336,510 & 246,477 & 90,033 & 73.2 & 26.8 \\
\hline Electrical Engineering & 6,784 & 5,811 & 973 & 85.6 & 14.4 \\
\hline Technology & 36,924 & 30,434 & 6,490 & 82.4 & 17.6 \\
\hline Arts and Humanities & 114,340 & 47,984 & 66,376 & 41.9 & 58.1 \\
\hline Education & 210,679 & 70,810 & 139,869 & 33.6 & 66.4 \\
\hline Economics & 715,041 & 432,146 & 282,895 & 60.4 & 39.6 \\
\hline Business Administration & 779,955 & 491,879 & 288,076 & 63.1 & 36.9 \\
\hline Law & 82,203 & 40,966 & 41,237 & 49.8 & 50.2 \\
\hline Medicine & 95,035 & 47,665 & 47,370 & 50.1 & 49.9 \\
\hline Nursing & 13,468 & 3,535 & 9,933 & 26.2 & 73.8 \\
\hline
\end{tabular}

Source: Turkish Higher Education Statistics 2019-2010.

As Stromquist noted, "the tendency for sexual inequality in women's education is not the result of deliberate policies of exclusion but unchallenged social norms regarding social roles of men and women" (1991, p.123). The education policies, which are, constructed on the notion of equal opportunity and the creation of a meritocratic society leaves the social norms regarding the social roles of men and women unchallenged (Brink \& Benschop, 2011). The education policies in Turkey fall short in questioning whether the system really enables girls and boys to realize their abilities to the full or whether their potential and abilities are given shape in accord with the different socioeconomic roles they are expected to perform. Equal opportunity policies assume that formal provision of education applies equally and undiscriminatingly to females and males. However, merely attempting to equalize existing patterns can exacerbate, because it can mask, fundamental sources of inequality.

\subsection{Basic Education Reform Act No. 4306}

The Basic Education Reform Act No. 4306 passed on August 18, 1997, promulgating compulsory education in a continuous eight-year format of primary education has marked a significant change in the enrollment patterns of girls and boys at the primary level. In accordance with this act MoNE launched the Basic Education Program (BEP), a 15-year program with a total estimated cost of USD11.3 billion, to expand the coverage of basic education (MoNE-APK, 1997; MoNE, 1998). The program funded primarily by the World Bank was to be carried out in two phases. The World Bank provided USD 300 million for each phase. The reform involved an intensive school building and renovation program, employment of thousands of new teachers and inspectors and improving the quality of education. The program prioritized the less-developed regions of Turkey such as Sirnak, Mardin, Van, Hakkari and Bitlis as well as the provinces in the Marmara region 
affected by the August, 1999, earthquake, in the construction and renovation of school buildings (MONE-APK, 1999)

The BEP encompasses measures taken in three different directions: quality, efficiency and equity. Integrating I/T (Information Technologies) in education, in- service training of teachers and inspectors, special education, improvements in basic education curricula, new educational materials and provision of educational materials to rural schools, and social assistance to students and families are the basic components of raising the quality of schools. Measures taken to improve efficiency can be as follows: establishing central schools in sparsely populated areas, shared utilization of resources such as teaching staff, physical capacity and educational materials and equipment. Equity measures are taken to reduce the educational disparities that exist between developed and less developed regions of Turkey.

The measures taken to reduce inequity can be as follows: the recruitment and stationing of qualified teachers in less developed areas, provision of free educational materials and equipment, and giving priority in construction and renovation of schools in the less developed provinces. The measures taken to increase access and retention of students can be grouped under three headings: a) bussing system, b) boarding schools and c) social assistance. The group who is supposed to benefit from these equity measures at the primary education level is intended to be children of ages 6-14 who live in lessdeveloped provinces of Turkey such as Sirnak, Hakkari, Bitlis, Mardin and Van. The provision of boarding schools and social assistance are another group of equity measures intended to increase the chances of talented and skilled students from low-income families to further their education.

It is assumed that with the expansion of educational provisions there will be an increase in the participation of students, both boys and girls. In fact, with the extension of compulsory education to 12 years, gender parity in primary and secondary education is achieved. As a result, the gender parity ratio for basic education increased from 0.93 in 2003-04 to 0.97 in 2007-08 and to 1 in 2012-13. Increases in the numbers of enrollment in primary education have in fact taken place for both sexes. Nevertheless, it has not proved very effective in cutting down the high dropout rates for girls in the underdeveloped regions of Turkey. Although attrition rates in the East and Southeast of Turkey have decreased after the passing of Basic Education Reform, they are still high especially for girls going to school in these regions.

\subsubsection{Attrition Rates in the East and Southeast Regions of Turkey}

The expansion of education as a result of the extension of compulsory education to 8 years in 1997 and later to 12 years in 2012 has had a limited impact in decreasing the high attrition rates evident in the underdeveloped regions of Turkey. In the Southeast and East regions of Turkey, which are the most economically deprived regions, a progressive decline is notable in the number of both boys and girls, but for girls the decline is much more noticeable. As can be seen in Table 2 while the average attrition rate in the southeast for boys is $25.9 \%$ for girls the attrition rate is 28.4 with $2.5 \%$ difference at the disadvantage of girls. The difference between boys and girls in attrition rates are even higher in the 
East. Table 3 indicates the attrition rates by sex in the Southeast region of Turkey. In the east while the attrition rate for boys is close to $30 \%$, for girls it is around $35 \%$. A quarter of the students who start $1^{\text {st }}$ grade drop out from the school system by the time they reach $8^{\text {th }}$ grade. However, in provinces like Diyarbakır, Mardin, Siirt, Bitlis, Muş, Ağrı and Erzurum the attrition rates for girls are much higher and this signals the fact that higher proportions of girls are kept away from school than boys.

Table 2: Attrition Rates in Primary Level (Grades 1-8) by Sex in the Southeast (2010-2018)

\begin{tabular}{|c|c|c|c|c|c|c|c|c|}
\hline \multirow[b]{2}{*}{ Southeast } & \multicolumn{2}{|c|}{$\begin{array}{c}\text { Number of students } \\
\text { enrolled in } 1^{\text {st }} \text { grade in } \\
2010-2011\end{array}$} & \multicolumn{2}{|c|}{$\begin{array}{c}\text { Number of students } \\
\text { enrolled in } 8^{\text {st }} \text { grade in } \\
2017-2018\end{array}$} & \multicolumn{2}{|c|}{ Difference } & \multicolumn{2}{|c|}{$\begin{array}{c}\text { Attrition } \\
\text { Rate }\end{array}$} \\
\hline & $\mathbf{M}$ & $\mathbf{F}$ & $\mathbf{M}$ & $\mathbf{F}$ & $\mathbf{M}$ & $F$ & $\mathbf{M}$ & $\mathbf{F}$ \\
\hline Diyarbakır & 23,386 & 23,681 & 16,699 & 15,799 & 6,687 & 7,882 & 28.6 & 33.3 \\
\hline Gaziantep & 23,654 & 22,765 & 18523 & 17,985 & 5,131 & 4,780 & 21.7 & 20.9 \\
\hline Mardin & 11,988 & 12,211 & 8818 & 8,367 & 3,170 & 3,844 & 26.4 & 31.5 \\
\hline Siirt & 5,230 & 5,141 & 3,718 & 3,344 & 1,512 & 1,797 & 28.9 & 34.9 \\
\hline Batman & 8,601 & 8,198 & 6469 & 6,224 & 2,132 & 1,974 & 24.7 & 24.0 \\
\hline Şırnak & 8,721 & 8,484 & 6,013 & 5,697 & 2,708 & 2,787 & 31.0 & 32.8 \\
\hline Kilis & 1,413 & 1,338 & 1,236 & 1,126 & 177 & 212 & 12.5 & 15.8 \\
\hline Southeast Total & 82,993 & 81,818 & 61,476 & 58,542 & 21,517 & 23,276 & 25.9 & 28.4 \\
\hline
\end{tabular}

Source: National Education Statistics-Formal Education, http://sgb.meb.gov.tr/www/resmiistatistikler/icerik/64.

Table 3: Attrition Rates in Primary Level (Grades 1-8) by Sex in the East (2010-2018)

\begin{tabular}{|c|c|c|c|c|c|c|c|c|}
\hline \multirow[b]{2}{*}{ East } & \multicolumn{2}{|c|}{$\begin{array}{l}\text { Number of students } \\
\text { enrolled in } 1^{\text {st }} \text { grade in } \\
2010-2011\end{array}$} & \multicolumn{2}{|c|}{$\begin{array}{c}\text { Number of students } \\
\text { enrolled in } 8^{\text {st }} \text { grade in } \\
2017-2018\end{array}$} & \multicolumn{2}{|c|}{ Difference } & \multicolumn{2}{|c|}{$\begin{array}{c}\text { Attrition } \\
\text { Rate }\end{array}$} \\
\hline & $\mathbf{M}$ & $\mathbf{F}$ & $\mathbf{M}$ & $\mathbf{F}$ & $\mathbf{M}$ & $\mathbf{F}$ & $\mathbf{M}$ & $\mathbf{F}$ \\
\hline Ăgrr1 & 11,324 & 14,094 & 5,325 & 5,083 & 5,999 & 9,011 & 52.9 & 63.9 \\
\hline Bingöl & 3,005 & 2,870 & 2351 & 2,236 & 654 & 634 & 21.7 & 22.09 \\
\hline Bitlis & 5253 & 5,319 & 3,487 & 3,195 & 1,766 & 2,124 & 33.6 & 39.9 \\
\hline 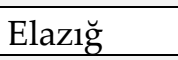 & 5,225 & 4,921 & 4,631 & 4,313 & 594 & 608 & 11.4 & 12.4 \\
\hline Erzurum & 9,162 & 9,620 & 6,717 & 6,565 & 2,445 & 3,055 & 26.6 & 31.7 \\
\hline Hakkari & 4,079 & 4,044 & 2840 & 2,731 & 1,239 & 1,313 & 30.4 & 30.6 \\
\hline Kars & 3,541 & 3,340 & 2,575 & 2,428 & 966 & 765 & 27.2 & 22.9 \\
\hline Muş & 8106 & 9,339 & 4376 & 3,824 & 3,730 & 5,515 & 46.0 & 59.0 \\
\hline Van & 17,964 & 17,800 & 11555 & 11,285 & 6,409 & 6,515 & 35.6 & 36.6 \\
\hline East Total & 82,223 & 84,971 & 43,857 & 41,660 & 23,802 & 29,540 & 28.9 & 34.7 \\
\hline
\end{tabular}

Source: National Education Statistics-Formal Education- http://sgb.meb.gov.tr/www/resmiistatistikler/icerik/64.

Equality of educational opportunity policies are generally based on the assumption that they will reduce existing inequalities by providing an expanded opportunity for a larger segment of the population to participate, particularly from traditionally deprived regions and rural areas of the country. Consequently, this would have a positive impact on the number of girls enrolling in schools as well. The Education Reform Act, Law No. 4306 in 1997 and (4+) Reform in 2012 by extending compulsory education to eight years and later 
to 12 years, has been successful in putting more girls in the formal schooling system. However, the dropout rates in the East and Southeast regions of Turkey continue to be high for boys and girls, but much higher for girls.

\subsubsection{Socialization and Distribution of Knowledge and Skills in Primary Education School Textbooks and Materials}

The Educational Reform Act, Law No. 4306 does not provide any special measures for the elimination of gender disparities that exist in schooling experiences. The definition of gender-related educational problems in schooling has been channeled to a limited view of education, which primarily focuses on gender parity in formal schooling. The inequitable distribution of skills and knowledge among girls and boys, men and women are not problematized. The socialization processes within schools that discriminate against girls are not questioned.

Three major studies in Turkey have been conducted on gender-stereotyping in educational textbooks. The first study (Arslan, 2000) was sponsored by the General Directorate of Women's Status and problems (GDWSP) and investigated messages and images on gender roles transmitted through the content and illustrations in textbooks published for the 1997-1998 school year. The second one was by Firdevs Gumusoglu (2008) on gender- stereotyping in primary education that included textbooks published between 1928-2008. The most recent study on gender-stereotyping in textbooks was conducted by Çimen \& Bayhan (2018) who compared the textbooks used in primary and secondary education in 2016-2017.

The earliest study on the depiction of gender roles in textbook was sponsored by the General Directorate of Women's Problems and Status (Arslan, 2000). The study examined 337 textbooks of the 1997-1998 school year in relation to the gender roles that were depicted in print and pictures. According to the GDWSP study, men constituted the majority of central characters. The character traits that were given to males and females reflected traditional gender roles. Women were depicted as affectionate, self-sacrificing, helpless, obedient-passive, and shy. The character traits that were emphasized the most in male characters were being a leader, initiator, successful, talented, firm, self-confident, brave and persevering. The printed material in primary education textbooks portrayed 44 different professions. Males were depicted in 42 professions whereas females were depicted in 10 professions. The professions males were concentrated in the most were high rank government officials such as prime minister, governor, etc. (32.8\%) followed by soldier $(15.9 \%)$, researcher and scientist $(10.0 \%)$. The types of profession females were represented in the most were housewife $(62.2 \%)$, followed by teacher $(8.1 \%)$ and housemaid $(8.1 \%)$. Women were not portrayed at all in any administrative, entrepreneurial, or engineering positions neither in printed nor in visual material. Only a very small percentage of men were portrayed as homemakers $(0.5 \%)$ in texts and none were portrayed as homemakers in pictures.

The second study on gender-stereotyping in school textbooks was conducted by Gümüşoğlu (2008) which examined 1500 textbooks published between 1928-2008. The textbooks that were examined fell within primarily two categories: textbooks that 
included topics on women and family such as in reading, history, life sciences, social sciences, home economics and practices, and citizenship, and textbooks that indirectly referred to gender roles via pictures or phrases such as in science, alphabet, and agriculture books. According to Gümüşoğlu, primary education textbooks written during the first 20 years of the Turkish Republic carried less gender stereotypes than the textbooks written after 1945. The textbooks of the republican period (1923-1945) were less sex biased and portrayed men and women as equal partners sharing household chores and responsibilities. However, after 1945 women are portrayed mostly in domestic roles, women as mothers and wives and girls as potential mothers. The apron becomes the main outfit of women substituting for the modem dress. The family picture where the mother is cooking or washing the dishes, the daughter assisting the mother in the household chores, the father reading a newspaper and the son studying becomes a common representation in many of the textbooks. Gümüşoğlu notes that the educators of the republican period were intentionally trying to avoid sexual stereotypes in order to construct a new type of individual who was self-sufficient and had a salient role in the shaping of the new republic. In the textbooks published after 1945 and onwards the spirit of constructing a modem identity for the Turkish people fades, leaving in its place to traditional mores and values.

Moreover, the curriculum change that took place in 2005 did little in addressing gender based discrimination or sexist implications and teachings in textbooks (Tan, 2005). The most recent study was conducted by Çimen \& Bayhan (2018) who compared the textbooks used in primary and secondary education in 2016-2017. Her conclusions were that the new curriculum was insubstantial in the portrayal of women's rights and gender equality. Statements on gender equality and women's rights were dropped from the $9^{\text {th }}$ grade textbooks, and the Turkish textbooks of $1^{\text {st }}$ and $5^{\text {th }}$ grade had a more sexist approach in both visual and written content. Women were portrayed in very limited professions, mostly housewives and there was no depiction of women in positions of political authority and power.

Discrimination in girls' access to education and training persists in many areas owing to stereotyped role models, inadequate and gender-biased teaching and educational materials which reduce girls' options for future choices (Amot \& Weiner, 1987; Grossman \& Grossman, 1994; Murphy \& Gipps, 1996; Stanworth, 1981). Thus, policies and practices in the area of socialization and skill development are also crucial in achieving gender equality in education.

\section{Conclusion}

Turkey depends on macro education policies without any gender differentiation to ensure educational equality. The education policies in Turkey are generally based on the assumption that they will reduce existing inequalities by providing an expanded opportunity for a larger segment of the population to participate, particularly from traditionally deprived regions and rural areas of the country. Consequently, this has had a positive impact on the number of girls enrolling in schools. However, the educational 
policies to extend educational opportunities have not reflected specific gender concerns. They have relied on gender-neutral policies to universalized education and, nonetheless, are far from challenging the gender dynamics that discriminate against girls and women. Gender is virtually ignored as an equity issue in any of the educational policies or statues enacted by the state.

The educational policies and practices in Turkey are based on the premises of "formal equality" and "meritocracy" which aims to provide the same opportunities to every member of society. In terms of gender, educational policies aim to achieve formal equality, "equal treatment" requiring women and men to be treated on the same terms without special barriers or favors due to their sex. Thus, gender equality in the Turkish educational context is about providing equal educational opportunities without any gender differentiation. However, the "same treatment" approach ignores the imbalance of power between men and women and the accumulation of advantage by males from traditional cultural practices and institutions still in existence, and thus, working against women. Moreover, the gender-neutral nature of educational policies serves to foster the belief that males and females are benefitting equally and serve to mask the inequitable distribution of knowledge and skills between men and women.

Article 42 of the Constitution, the Basic Law of National Education. Law 1739, The Basic Education Reform Act. No. 4306 and 4+Reform focuses on the expansion and improvement of primary and secondary education, but does not carry any special measures for the gender disparities that exist in attainment and schooling experiences. A good level of net schooling enrolment rate has been achieved - and this is important but nothing has been done to change the structures and relations that discriminate against girls. Increases in the numbers of enrollment in primary education have in fact taken place for both sexes. However, high female attrition rates especially in the underdeveloped regions of Turkey continue to exist.

The Ministry of Education incorporates a functional view of education, in which the concept of meritocracy is central to the formation of policies and practices. Schools are seen as agencies working to create a more meritocratic society: a society of equal opportunity where status and power depend upon ability and effort. Moreover, almost in all major educational policy documents emphasis is on providing education in accord with individual talents, abilities, and interests. From this notion of education that gives priority to individual interests and skills, one is to presume that the subject choices made by students at all educational levels is a reflection of individual skill and interest, without taking into account the fact that they can be reflections of preconceived notions of what is "right" for females and males. Another aspect of providing programs according to interest and skill perpetuates the gender segregation in occupational choices. The Higher Education Statistics of 2018-2019 reveal that gender-streaming is still apparent in the programs males and females enroll.

Recent studies, moreover, indicate textbooks continue to contain messages, depictions and illustrations that present women in subordinate positions and in conventional nurturing and servicing roles (Tan, 2005; Çimen \& Bayhan, 2018). Primary education textbooks continue to reflect gender-role stereotypes and thus contribute to the 
conditioning of differential behavioral norms for girls and boys. No national policies to counter the impact of negative socialization by curriculum and textbook revision have been adopted. In policy documents that were examined, there is no mention of gendered structures, educational relations or pedagogies within the school that would lead to gender-aware educational environments, processes, and outcomes.

Education for all children is assumed to be of national importance tied to social and economic progress, with meritocratic assumptions that education raises individual's opportunities. Especially in the Basic Law of National Education No. 1739, and in almost all of the National education conventions and Five-year Development Plans, "equality of opportunity" has been included in the rhetoric of educational policymaking, whether it meant the provision of scholarships to the talented and skilled students who did not have sufficient funds to continue their education or it meant the expansion of education to increase the relative opportunities of the disadvantaged. However, the functional view of schooling based on the concepts of "formal equality" and "meritocracy" undermines the social, cultural and material conditions that constrain the possibilities of women to the advantage of men.

\section{Recommendations}

In every decision that is made a gender analysis needs to be made to determine how that decision will impact women and men, respectively. Thus, gender issues become an integral part of every policy that is made concerning men and women. This is a necessary step to eradicate the discrimination that occurs against women due to "gender-neutral" mainstream polices, which in fact serve the interests of men. Because there is no gender analysis in equal opportunity polices, they don't take into account how certain equal opportunity policies work for the disadvantage of females.

The Turkish government has given attention toward the provision of basic education as a principle of economic and political development. The increase of the provision of compulsory education to 12 years has resulted in significant gains in primary and secondary education for both boys and girls. However, not much attention has been given to attaining gender equity in education and schooling. Policies and practices need to incorporate gender equity issues in their agenda. Moreover, the allocation of sufficient funds for the implementation and monitoring of gender equity issues are crucial.

The state needs to recognize that discrimination is not an individual problem but a social problem. If women are seen as the problem, policies will function as remedial measures. Initiatives that focus on long-term goals to eliminate unequal relations within both the education system and the broader society needs to be part of gender policy agendas.

\subsection{Limitations}

The study attempts to link state policies to gendered outcomes in education. However, as Stromquist (1997) points out, "analysis of policy impact are methodologically difficult because of the impossibility of establishing a clear causal link between macro-decisions (the law) 
and micro-consequences (outcomes at the individual level), since numerous other events in society take place simultaneously" (p.55). This study can only provide an understanding between policies and educational outcomes. However, it cannot claim that educational outcomes are the result of policies.

\section{About the Author}

Berna Çöker is an Assistant Prof. at Dokuz Eylül University, Buca Faculty of Education. She received her M.A from Teachers College, Columbia University and her PhD from University of Southern California, Dept. of International and Intercultural education. She has been involved in a number of projects supported by U. N. Inter-Agency Network and the European Union. She is currently teaching in the Department of Early Childhood Education. Berna Çöker has a wide range of research interests, including teaching English to young learners, language learning and teaching, literacy development, inclusive education and international education.

\section{References}

Ali, S., Benjamin, S. \& Mauthner, M. (2004). The politics of gender and education: Critical perspectives. London: Palgrave Macmillan.

Alat, Z. \& Alat, K. (2011). A qualitative study of parental resistance to girls' schooling. Educational Sciences: Theory and Practice, (11)3, 1369-1373.

Arslan, S. A. (2000). Ders kitaplarında cinsiyetçilik [Sex-stereotyping in textbooks). Ankara: General Directorate of Women's Status and Problems.

Arnot, M. \& Weiner, G. (1989). Gender and politics of schooling. London: Unwin Hyman. Aydagül, B. (2019). Turkey's progress on gender equality in education rests on gender politics. Turkish Policy Quarterly, 18 (1), 45-57.

Ball, S. J. \& Gerwirtz, S. (1997). Girls in the education market: choice, competition and complexity. Gender and Education, 9(2), 207-222.

Baron, A. (1987). Feminist legal strategies: The powers of difference. In B.B. Hess \& M.F. Ferree (Eds.), Analyzing gender: A handbook of social science research, (pp. 3254). Newbury Park, CA: Sage Publications.

Binay, H. (1992). Education in Turkey. Ankara: MEB.

Börkan, B., Levent, H., Dereli, O., Bakış, O. ve Pelek, S. (2014). Temel belirleyicileri açısından ilköğretimde okula devam ve devamsızlık. Ankara: MEB, ERG ve UNICEF

Brink, M. \& Benschop, Y. (2011). Gender practices in the construction of academic excellence: Sheep with five legs. Organization 19(4):507-524. https://doi.org/10.1177/1350508411414293

Burstyn, V. (1985). Masculine dominance and the state. In V. Burstyn \& D. Smith (Eds.), Women, class, family and the state (pp.45-89). Toronto: Garamond 
Cin, M. F., \& Walker, M. (2016). Reconsidering girls' education in Turkey from a capabilities and feminist perspective. International Journal of Educational development, 49, 134-143. https://doi.org/10.1016/j.ijedudev.2016.02.007

Cin, M., F., Karlıdağ-Dennis, E. \& Temiz, Z. (2020). Capabilities-based gender equality analysis of educational policy-making and reform in Turkey. Gender and Education, 32:2, 244-261. https://doi.org/10.1080/09540253.2018.1484429

Connell, R. W. (1987). Gender and power. Cambridge: Polity.

Crudas, L. \& Haddock, L. (2005). Engaging girls voices: learning as social practice. In Problem girls: understanding and supporting troubled and troublesome girls and young women. London: Routledge .

Çimen, C. A., \& Bayhan, S. (2018). Ders Kitaplarında Sekülerizm ve Toplumsal Cinsiyet Eşitliği Araştırması Sonuç Raporu [Secularism in Class Books and Findings of the Gender Equality Report], Karşılaştırmalı Eğitim Derneği.

David, M. (2004). A feminist critique of public policy discourses about educational effectiveness. In The politics of gender and education: critical perspectives, (Eds) Ali, S., Benjamin, S. \& Muthner, M. L. Basingstoke: Palgrave.

Demiray, E. (2015). Problems in women's education in Turkey. Implementations and suggested solutions. International Journal on New Trends in Education and Their Implications, $6(1), 1-12$

Duman, A. (2010). Female Education Inequality in Turkey: Factors Affecting Girls' Schooling Decisions. International Journal of Education Economics and Development 1 (3): 243-258.

Eisenstein, Z. R. (1979). Capitalist patriarchy and the case for socialist feminism. New York: Monthly Review Press.

Eisenstein, Z. R. (1988). The female body and the law. Berkeley, CA: University of California Press.

Eisenstein, H. (1996). Inside agitators: Australian femocrats and the state (women in the political economy). Philadelphia: Temple UP.

Francis, B. \& Skelton, C. (2005). Reassessing gender and achievement: questioning contemporary key debates. London: Routledge

Gamble, S. (2001). The Routledge companion to feminism and postfeminism. New York: Routledge.

Grossman, H. \& Grossman, S. H. (1994). Gender issues in education. Boston: Allyn and Bacon.

Gümüş, S. \& Chudgar, A. (2016). Factors affecting school participation in Turkey: an analysis of regional differences. Compare: A Journal of Comparative and International Education, (46)6, 929-951, DOI: 10.1080/03057925.2015.1095073.

Gümüşoğlu, F. (2008). Ders kitaplarında toplumsal cinsiyet: Toplum ve demokrasi, [Gender in school textbooks: society and democracy]. 2 (4), 39-50.

Hauserman, N. (1983). Sexual equality: An essay on the importance of recognizing difference. Legal Studies Forum. 7, 251-169.

Jenson, J. (1986). Gender and reproduction: or, babies and the state. Studies in Political Economy. 20, 9-46. 
Kenway, J. (1990). Gender and education policy: a call for new directions. Victoria: Deakin University Press.

Kogan, M. (2018). Educational policy-making: A study of interest groups and parliament. Taylor \& Francis.

Kariya, T. \& Rappleye, J. (2020). Education, Equality, and Meritocracy in a Global Age: The Japanese Approach. International Perspectives on Educational Reform Series. New York: Teachers College

Mackinnon, C. A. (1983). Feminism, Marxism, method, and the state: Toward feminist jurisprudence. Signs, 8, 635-658.

Marshal, C. (1997). Dismantling and reconstructing policy analysis. In C. Marshal (Ed.), Feminist critical analysis I: A perspective from primary and secondary schooling (p.1-39). London: Falmer.

Maslak, M. A. (2005). Re-positioning Females in the International Educational Context: theoretical frameworks, shared policies, and future directions. Global Trends in Educational Policy, vol. 6, 145-171. Oxford: Elsevier.

McIntosh, M. (1978). The state and the oppression of women. In A, Kuhn and A.M. Wolpe (Eds.), Contemporary feminist debates. Oxford: Polity.

MoNE. (1990). Apprenticeship and vocational-technical education council meetings and resolutions. Ankara: Meb

MoNE. (1993). Ondorduncu Milli Egitim Surasi. 27-29 Evlul: Raporlar. gorusmeler ve kararlar [Fourteenth national education convention, 27-29 September; Reports, meetings and resolutions]. Istanbul: Meb.

MoNE-APK (1997). Non-stop eight-year compulsory Primary education. [Sekiz Y1llık Kesintisiz Zorunlu İlköğretim] MoNE Research, Planning and Coordination Dept. Publication Ankara: Ajans Türk Basın ve Basım Inc.

MoNE (1998). Expanding eight-year continuous compulsory Primary education [Sekiz Yıllık Kesintisiz Zorunlu İlköğretimin Yaygınlaştırılması Raporu], Yayınlanmamış Rapor, Ankara,

MoNE-APK (1999). Non-stop eight-year compulsory Primary education-2. [Sekiz Yillık Kesintisiz Zorunlu İlköğretim -2]Ankara: T.C. MoNE Research, Planning and Coordination Dept. Publication.

Murphy, P. \& Elwood, J. (1998). Gendered learning outside and inside school: influences on achievement. Failing boys? Issues in gender and achievement. Buckingham: Open University Press

National Education 2010-2011. http://sgb.meb.gov.tr/meb iys dosyalar/2012 12/06021014 meb istatistikleri org un egitim 2010 2011.pdf. Accessed June 15, 2020.

National Education Statistics-Formal 2018-2019. http://sgb.meb.gov.tr/meb iys dosyalar/2018 09/06123056 meb istatistikleri org un egitim 2017 2018.pdf. Accessed June 15, 2020.

Niemi, N. (2005). The emperor has no clothes: examining the impossible relationship between gendered and academic identities in middle school students. Gender and Education. 17(5): 483-497. 
Osler, A., Street, C., Lall, M. \& Vincent, C. (2002). Not a problem? Girls and exclusion from school. York: Joseph Rowntree Foundation.

Peterson, S. V. \& Runyan, A. S. (1993). Global gender issues. Boulder, CO: Westview.

Pratt, J., Bloomfield. J., \& Seale, C. (1984). Option choice: A question of equal opportunity. Windsor: NFER- Nelson.

Prunty, J. (1985). Signposts for Critical Policy Analysis Work, Australian Journal of Education, 29 (2) p133-40.

O’Dwyer, J., Aksit, N \& Sands. M. (2010). Expanding Educational Access in Eastern Turkey: A New Initiative. International Journal of Educational Development 30 (2): 193-203. DOI: 10.1016/j.ijedudev.2009.03.005.

Petchesky, R. (1984). Abortion and women's choice: The state, sexuality and reproductive freedom. New York: Longman.

Pratt, J., Bloomfield. J., \& Seale, C. (1984). Option choice: A question of equal opportunity. Windsor: NFER- Nelson.

Randall, V. and Waylen G. (Eds.) (1998). Gender, politics and the state. London: Routledge.

Riordan, C. (1990). Girls and boys in school: Together or separate? New York: Teachers College Press.

Schaar, J. H. (1971). Equality of opportunity and beyond. In A. de Cresigny \& A. Wertheimer (Eds.), Contemporary political thought (pp. 123-165). London: Nelson

Stanworth, M. (1981). Gender and schooling: A study of sexual divisions in the classroom. London; Hutchinson.

Stromquist, N., P. (1991). Educating women: The political economy of patriarchal states. International Studies in Sociology of Education, (1), 111-127.

Stromquist, N. P. (1997). Gender policies in American education: Reflections on federal legislation and action. In C. Marshall (Ed.), Feminist critical policy analysis I: A perspective from primary and secondary schooling. London: Falmer.

Sutherland, M. B. (1999). Evaluating national policies on gender issues. In S. Erskine and M. Wilson (eds.), Gender issues in international education: Beyond policy and practice (pp.3-22). New York: Falmer press.

Tan, M. (2005). Yeni ilkogretim programlari ve toplumsal cinsiyet (New curriculum and gender in education) Egitim, Bilim, Toplum Dergisi, 3 (11), 68-77.

Turkish Higher Education Statistics, 2019-2020 https://istatistik.yok.gov.tr/. Accessed June 15, 2020.

Unterhalter, E. (2005). Fragmented Frameworks: Researching Women, Gender, Education and Development. In Beyond Access: Developing Gender Equality in Education, edited by S. Aikman, and E. Unterhalter, 15-35. Oxford: Oxfam

Walby, S. (1990). Theorizing Patriarchy. Oxford: Blackwell.

World Economic Forum (2020). Global Gender Gap Report 2020. http://www3.weforum.org/docs/WEF GGGR 2020.pdf. Accessed June 152020. 
Author(s) will retain the copyright of their published articles agreeing that a Creative Commons Attribution 4.0 International License (CC BY 4.0) terms will be applied to their work. Under the terms of this license, no permission is required from the author(s) or publisher for members of the community to copy, distribute, transmit or adapt the article content, providing a proper, prominent and unambiguous attribution to the authors in a manner that makes clear that the materials are being reused under permission of a Creative Commons License. Views, opinions and conclusions expressed in this research article are views, opinions and conclusions of the author(s). Open Access Publishing Group and European Journal of Education Studies shall not be responsible or answerable for any loss, damage or liability caused in relation to/arising out of conflicts of interest, copyright violations and inappropriate or inaccurate use of any kind content related or integrated into the research work. All the published works are meeting the Open Access Publishing requirements and can be freely accessed, shared, modified, distributed and used in educational, commercial and non-commercial purposes under a Creative Commons Attribution 4.0 International License (CC BY 4.0). 